\title{
Physiological ageing in a temperate and a polar swimming scallop
}

\author{
Eva Philipp ${ }^{1}$, Thomas Brey ${ }^{1}$, Olaf Heilmayer ${ }^{2}$, Doris Abele ${ }^{1, *}$, Hans-Otto Pörtner ${ }^{1}$ \\ ${ }^{1}$ Alfred-Wegener-Institut für Polar- und Meeresforschung, Ökophysiologie, 27568 Bremerhaven, Germany \\ ${ }^{2}$ Florida Atlantic University, Department of Biological Sciences, Boca Raton, Florida 33431, USA
}

\begin{abstract}
We compared physiological ageing parameters in 2 scallops, the temperate Aequipecten opercularis and the Antarctic Adamussium colbecki. These 2 species are phylogenetically closely related and display a similar lifestyle but have distinctly different maximum lifespans (MLSP). A. opercularis does not live longer than 8 to $10 \mathrm{yr}$, whereas A. colbecki lives over $18 \mathrm{yr}$. The development of several physiological ageing parameters over time, chosen according to the 'free radical theory of ageing', was compared in the 2 species to identify differences in the ageing process. In the shorter-lived $A$. opercularis, activities of the mitochondrial enzymes citrate synthase and cytochrome $c$ oxidase and of the antioxidant enzyme catalase showed a more pronounced decrease with increasing age than in the longer-lived A. colbecki. In line with this finding, lipofuscin accumulation increased more distinctly in A. opercularis than in A. colbecki, while tissue protein content decreased in A. opercularis but increased in A. colbecki. Its better preservation of mitochondrial and antioxidant enzyme activities and the avoidance of waste accumulation may enable $A$. colbecki to live longer than $A$. opercularis. Mitochondrial function investigated in A. opercularis showed only minor changes with age, and mitochondrial $\mathrm{H}_{2} \mathrm{O}_{2}$ generation rates were low at all ages. We relate our findings to the 'free radical-rate of living' theory, to the 'uncoupling to survive' hypothesis, and to the particular lifestyle of these scallops.
\end{abstract}

KEY WORDS: Ageing $\cdot$ scallops $\cdot$ Reactive oxygen species $\cdot$ ROS $\cdot$ Mitochondria

\section{INTRODUCTION}

There is much empirical evidence for higher maximum lifespans (MLSP) in cold-adapted ectotherms compared to their close relatives from temperate waters (Brey 1991, Brey et al. 1995, Ziuganov et al. 2000, Cailliet et al. 2001, La Mesa \& Vacchi 2001, Philipp et al. 2005a). We aim to explore the physiological principles underlying those differences in MLSP, especially with respect to the accelerating effect of temperature on aerobic metabolic rates and reactive oxygen species (ROS) formation.

Two ageing theories link ageing and MLSP to mitochondrial ROS formation: (1) The 'free radicalrate of living' theory (Pearl 1928, Harman 1956) predicts a negative correlation between standard metabolic rate (SMR) and MLSP due to increased mitochon- drial production of ROS at higher SMR (Ku et al. 1993); in some species, however, this strict relationship between MLSP and SMR is not maintained, especially in primates and birds, which live longer than expected from their SMR (Pérez-Campo et al. 1998). (2) The 'uncoupling to survive' hypothesis by Brand (2000) attempts to explain this contradiction by proposing that mitochondrial uncoupling modulates ROS production, thus altering the strict dependency of ROS formation on SMR.

A recent comparison of sessile infaunal soft-shell clams from temperate regions (Mya arenaria) and from Antarctica (Laternula elliptica) (Philipp et al. 2005a,b), showed that lower metabolic rates of the Antarctic $L$. elliptica, along with the maintenance of a reduced tissue redox-state, lower mitochondrial $\mathrm{H}_{2} \mathrm{O}_{2}$ generation, and a less pronounced decline in mitochondrial func- 
tions (aerobic capacity, respiratory control ratio [RCR], proton leak) could form the basis for the extended lifespan of the Antarctic species compared to the temperate $M$. arenaria.

The present study extends our approach to actively swimming bivalves, to see whether there are unifying principles of physiological ageing in bivalves or whether an active and energy-consuming lifestyle leads to different strategies regarding maintenance of physiological fitness. The temperate queen scallop Aequipecten opercularis is found along the European coast from Norway to the Mediterranean and from the Adriatic to the west of Ireland, spanning an overall temperature range from 6 to $24^{\circ} \mathrm{C}$ (Ansell et al. 1991). The Antarctic scallop Adamussium colbecki is a common member of Antarctic coastal communities, where it experiences a habitat temperature range of -1.8 to $2.5^{\circ} \mathrm{C}$ (Berkman 1990, Berkman et al. 2004). Both pectinids are epibenthic with a well-developed capacity of jet-propulsion for swimming (Brand 1991, Ansell et al. 1998). Despite their close phylogenetic relationship (Canapa et al. 2000) and principal similarity in their lifestyle, the 2 species differ distinctly in maximum lifespan. A. opercularis has a relatively short MLSP which does not exceed 8 to 10 yr (Ansell et al. 1991). A. colbecki is a slow-growing, long-lived species, but its exact MLSP is, however, still unknown. Chiantore et al. (2003) reported an individual of $18 \mathrm{yr}$ of age, inferred from a von Bertalanffy growth function. Berkman et al. (2004) recaptured scallops after a 12 yr period, which had been already large adults when released. According to these and other studies (Berkman 1990, Cattaneo-Vietti et al. 1997, Heilmayer et al. 2003) a MLSP of 30 to 40 yr for $A$. colbecki is most likely.

\section{MATERIALS AND METHODS}

Sampling and maintenance. Aequipecten opercularis: A. opercularis were dredged from the Irish Sea 15 nautical miles south of Port St. Mary, Isle of Man, in July-August 2003 at about $64 \mathrm{~m}$ water depth. Scallops were transported to the Port Erin Marine Laboratory and kept in natural seawater flow-through aquaria at $\sim 10^{\circ} \mathrm{C}$ and 34 PSU for several days prior to experimentation. Experiments with isolated mitochondria were carried out at the Port Erin Marine Laboratory. Specimens for whole animal respiration were transported in thermo boxes to the Alfred Wegener Institute in Bremerhaven, Germany. For all other analyses, samples were freeze-clamped immediately and stored in liquid nitrogen for transportation to the Alfred-WegenerInstitute, Bremerhaven.

Adamussium colbecki: Antarctic A. colbecki were dredged at Terra Nova Bay ('Road Bay', 74²43' S, $\left.164^{\circ} 13^{\prime} \mathrm{E}\right)$ in February 2004. Scallops were either sacrificed after collection and the mantle tissue stored in liquid nitrogen, or frozen whole in liquid nitrogen. Samples were transported in liquid nitrogen from Antarctica to Genova, Italy, and at $-80^{\circ} \mathrm{C}$ from Genova to the Alfred Wegener Institute in Bremerhaven.

Age determination. External annual shell growth checks were used to establish relations between shell height and age in both species. For Aequipecten opercularis we aged 76 individuals and took an additional 200 height-at-age data from Allison (1993). For Adamussium colbecki, 185 height-at-age data pairs of the Terra Nova population were taken from Heilmayer et al. (2003). The von Bertalanffy growth function (VBGF)

$$
H_{t}=H_{\infty} \times\left(1-\mathrm{e}^{-k \times\left(t-t_{0}\right)}\right)
$$

was used to model the relation between shell height and age, where $H_{t}$ is height at Age $t_{1} H_{\infty}$ is height at infinite age, $k$ is the growth constant, and $t_{0}$ is age at which size would be zero (for details see Brey 2001 http://www.awi-bremerhaven.de/Benthic/Ecosystem/ FoodWb/Handbook/main.html Alfred Wegener Institute for Polar and Marine Research, Germany). To estimate Age $t$ from size $H_{t}$ of our experimental scallops, we fitted the inverse VBGF

$$
t=\ln \left(1-H_{t} / H_{\infty}\right) /-k+t_{0}
$$

to the height-at-age data sets using the non-linear, iterative Newton algorithm.

Metabolic rate. The SMR of Aequipecten opercularis $(\mathrm{N}=31$, mass range 219 to $3411 \mathrm{mg}$ ash-free dry mass [AFDM], size range 30 to $80 \mathrm{~mm}$, age range 1 to $6 \mathrm{yr}$ ) was measured at $10^{\circ} \mathrm{C}$ and $34 \mathrm{PSU}$ in a multichannel, modified, intermittent-flow system with oxygen microoptodes connected to a Microx TX 2-array (PreSens), as previously described in Gatti et al. (2002). Microoptodes were calibrated to $100 \%$ oxygen solubility in air-saturated seawater and to $0 \%$ in $\mathrm{N}_{2}$-saturated seawater at the experimental temperature of $10^{\circ} \mathrm{C}$. Prior to respiration measurements, individuals of $A$. opercularis were maintained without food for $3 \mathrm{~d}$ to eliminate effects of specific dynamic action (SDA).

The respiration chambers (200 to $650 \mathrm{ml}$ ) were placed in a plastic tub with filtered seawater; a peristaltic pump (Ismatec) ensured continuous water circulation. To reduce handling stress, scallops were allowed to accommodate to the respiration chambers overnight. After closing the respiration chambers, a decrease in oxygen content from 100 to about $70 \%$ oxygen over a time of 2 to $3 \mathrm{~h}$ was recorded. Individuals were measured 2 to 3 times. After measurement, the scallops were dissected and soft tissue wet mass and dry mass ( $3 \mathrm{~d}$ at $60^{\circ} \mathrm{C}$ ) were determined. Tissues were combusted at $500^{\circ} \mathrm{C}$ for $5 \mathrm{~h}$ to determine the AFDM. SMRs were de- 
termined after subtraction of the microbial oxygen demand of the system, determined in a parallel blank chamber. Percent $\mathrm{O}_{2}$ saturation was transformed to micromoles of dissolved oxygen in seawater, using known values of oxygen solubility (according to Benson \& Krause 1984) and converted to $\mu \mathrm{g} \mathrm{O}_{2}$.

Mitochondrial measurements. Isolation: Mitochondria were isolated from the mantle tissue of freshly sacrificed bivalves. Tissues of up to 3 individual Aequipecten opercularis specimens were pooled for 1 experiment. About $3 \mathrm{~g}$ of mantle tissue were finely chopped in $10 \mathrm{ml}$ ice-cold homogenisation buffer, modified after Moyes et al. (1985) (400 mM sucrose, 70 mM HEPES, $100 \mathrm{mM} \mathrm{KCl}, 3 \mathrm{mM}$ ethylenediaminetetraacetic acid [EDTA], $6 \mathrm{mM}$ ethelyneglycol-bis-tetraacetic acid [EGTA], $1 \%$ bovine serum albumine, $1 \mu \mathrm{ml}^{-1}$ aprotinine, $\mathrm{pH}$ 7.3).

Briefly, the tissue was homogenised in a pre-cooled glass/teflon-homogeniser, centrifuged at $1300 \times g$ for $15 \mathrm{~min}$ at $2^{\circ} \mathrm{C}$, and the supernatant collected. The pellet was resuspended and homogenised, and again mitochondria were separated at the same speed. The 2 supernatants were combined and centrifuged at $10500 \times g$ for $10 \mathrm{~min}$ to sediment the mitochondria. The resulting mitochondrial pellet was resuspended in 1.5 to $2 \mathrm{ml}$ assay medium (560 mM sucrose, $100 \mathrm{mM} \mathrm{KCl}$, $10 \mathrm{mM} \mathrm{KH}_{2} \mathrm{PO}_{4}, 70 \mathrm{mM}$ HEPES, $5 \mathrm{mM}$ glutamate, $1 \mu \mathrm{g}$ $\mathrm{ml}^{-1}$ aprotinine and $1 \%$ bovine serum albumine, $\mathrm{pH}$ 7.3).

Respiration: Mitochondrial respiration measurements were carried out at $10^{\circ} \mathrm{C}$. Respiration rate was recorded with oxygen microoptodes (PreSens). Oxygen concentrations were calculated using oxygen solubility $\left(\mathrm{BO}_{2}\right)$ according to Johnston et al. (1994) and the atmospheric pressure on the relevant day. We used $5 \mathrm{mM}$ succinate, with $5 \mu \mathrm{M}$ rotenone to prevent respiration of endogenous NAD-linked substrates (Brand 1995), as substrate, and State 3 respiration was induced by addition of $0.15 \mathrm{mM}$ ADP. Non-phosphorylating respiration, oxygen consumption due to proton leakage and ROS formation (State $4+$ ) were recorded after adding $2 \mu \mathrm{g} \mathrm{ml}^{-1}$ of the $F_{0} F_{1}$-ATPase inhibitor oligomycin. The percentage of proton leak of State 3 oxygen consumption was calculated as (State $4+/$ State 3 ) $\times 100$. The respiratory control ratio (RCR), which describes how effectively the respiratory chain is coupled to the ATPase, was calculated according to Estabrook (1967), using State 4+ respiration. The ADP:O ratio was determined by recording the time used for the consumption of the given ADP and the corresponding oxygen consumption.

Hydrogen peroxide $\left(\mathrm{H}_{2} \mathrm{O}_{2}\right)$ production: Mitochondrial hydrogen peroxide production was measured fluorimetrically $\left(\lambda_{\text {exitation }}=312 \mathrm{~nm}\right.$ and $\left.\lambda_{\text {emission }}=420 \mathrm{~nm}\right)$ by recording the reaction of $\mathrm{H}_{2} \mathrm{O}_{2}$ with homovanilic acid (HVA) in the presence of horse radish peroxidase
(HRP), using a procedure modified after Miwa et al. (2003). Measurements of the $\mathrm{H}_{2} \mathrm{O}_{2}$ generation rate of Aequipecten opercularis mitochondria were performed with a Shimadzu (RF-1501) fluorometer at the Port Erin Marine Laboratory, as described in detail by Philipp et al. (2005b) for Laternula elliptica. Both $\mathrm{H}_{2} \mathrm{O}_{2}$ generation rates and oxygen consumption rates were measured in parallel and related to mitochondrial protein content (for details see Keller et al. 2004).

Enzyme assays. Enzyme activity was measured in mantle tissue of Aequipecten opercularis and Adamussium colbecki. All samples were measured at a reference temperature of $20^{\circ} \mathrm{C}$. To investigate temperature sensitivity of the different enzymes $\left(Q_{10}\right.$ values), enzyme activities were also determined at 0 to $5^{\circ} \mathrm{C}$ for A. colbecki and at $10^{\circ} \mathrm{C}$ for A. opercularis. The range of experimental temperatures given for $A$. colbecki data arose from the difficulty in achieving stable thermal conditions in the low temperature range. We therefore recorded the exact temperature in each assay and variations in temperature were taken into account for $Q_{10}$ calculations. Data are expressed as international units ( $\mu \mathrm{mol}$ of substrate converted to product $\mathrm{min}^{-1}$ ) per $\mathrm{mg}$ protein. Protein content of the extracts was determined by the Biuret method (Kresze 1988).

Superoxide-dismutase (SOD, EC 1.15.1.1). Superoxide-dismutase (SOD) was determined after Livingstone et al. (1992). Frozen mantle tissue was ground in liquid nitrogen and homogenised in Tris buffer (20 mM TRIS$\mathrm{HCl}, 1 \mathrm{mM}$ EDTA, pH 7.6) 1:8 (w/v). Samples were centrifuged for $3 \mathrm{~min}$ at $18000 \times g$ and at $2^{\circ} \mathrm{C}$. SOD activity was measured as degree of inhibition of the reduction of cytochrome $c$ by superoxides generated by a xanthine oxidase/xanthine system at $550 \mathrm{~nm}$ in $43 \mathrm{mM}$ potassium buffer with $0.1 \mathrm{mM}$ EDTA, pH 7.8. 1 U SOD causes $50 \%$ inhibition under assay conditions.

Catalase (EC 1.11.1.6): Catalase activity was determined after Aebi (1984). Frozen mantle tissue was ground in liquid nitrogen and homogenised in $50 \mathrm{mM}$ phosphate buffer (50 mM KH $\mathrm{KO}_{4}, 50 \mathrm{mM} \mathrm{Na} \mathrm{HPO}_{4}$, $\mathrm{pH} 7.0)$ with $0.1 \%$ Triton $\mathrm{x}-100$ at $1: 5(\mathrm{w} / \mathrm{v})$. Samples were centrifuged at $13000 \times g$ for $15 \mathrm{~min}$ at $2^{\circ} \mathrm{C}$. The activity was determined by recording the period required for $\mathrm{H}_{2} \mathrm{O}_{2}$ decomposition, resulting in a decrease of absorption from 0.45 to 0.4 at $240 \mathrm{~nm}$.

Citrate synthase (CS, EC 4.1.3.7) and cytochrome $C$ oxidase (COX, EC 1.9.3.1): Frozen mantle tissue was ground in liquid nitrogen and homogenised with a glass homogeniser (Nalgene) in Tris-HCl buffer (20 mM Tris-HCl, 1 mM EDTA, $0.1 \%$ (v/v) Tween ${ }^{\circledR} 20$, $\mathrm{pH}$ 7.4), 1:4 (w/v) for CS and 1:3 (w/v) for COX.

Homogenates for CS activity were sonicated for 15 min in a Branson Sonifier 450 (output control 8, Duty cycle $50 \%$ ) cooled to $0^{\circ} \mathrm{C}$ and centrifuged at $7400 \times g$ for $5 \mathrm{~min}$ at $2^{\circ} \mathrm{C}$. CS activity was measured 
after Sidell et al. (1987) by recording the absorbance increase of $0.25 \mathrm{mM}$ DTNB (5,5'dithiobis [2-nitrobenzoic acid]) in $75 \mathrm{mM}$ Tris $\mathrm{HCl}$ (pH 8.0), $0.4 \mathrm{mM}$ acetyl$\mathrm{CoA}$ and $0.4 \mathrm{mM}$ oxaloacetate at $412 \mathrm{~nm}$. Activity was calculated using the extinction coefficient $\varepsilon_{412} \mathrm{mM}$ of $13.61 \mathrm{mM}^{-1} \mathrm{~cm}^{-1}$.

For COX measurements, homogenates were centrifuged for $10 \mathrm{~min}$ at $1000 \times g$ and $2^{\circ} \mathrm{C}$. COX activity was determined after Moyes et al. (1997) by measuring the oxidation rate of cytochrome $c$ at $550 \mathrm{~nm}$ in $20 \mathrm{mM}$ Tris $\mathrm{HCl}$ buffer with $0.5 \%$ Tween 20, pH 8.0. Activity was calculated using the extinction coefficient $\varepsilon_{550} \mathrm{mM}$ $19.1 \mathrm{mM}^{-1} \mathrm{~cm}^{-1}$ after Hardewig et al. (1999).

Glutathione content. The concentrations of the oxidised (GSSG) and the reduced form (GSH) of glutathione were measured using high-performance liquid chromatography (HPLC) with a method modified after Fariss \& Reed (1987) (for more details see Philipp et al. 2005a). The measurement is based on the derivatisation of the thiols with dinitrofluobenzene (DNFB). GSH oxidation during extraction is prevented by iodoacetic acid (IAA) binding of GSH. The HPLC system consisted of an $\mathrm{NH}_{2}$-spherisorb column $(240 \times 4 \mathrm{~mm}, 5 \mu \mathrm{m}$ particles) at $39^{\circ} \mathrm{C}$ and a binary solvent system of $80 \%$ methanol/water (Solvent A) and $80 \%$ Solvent A/20\% acetate stock (272 $\mathrm{g} \mathrm{Na}$-acetate-trihydrate diluted in $122 \mathrm{ml}$ water plus $378 \mathrm{ml}$ glacial acetic acid) (Solvent B). Flow rate was $1.2 \mathrm{ml} \mathrm{min}^{-1}$ at a maximum backpressure of 2500 pounds per square inch (psi). The gradient programme was $85 \%$ Solvent A/15\% Solvent B for $8 \mathrm{~min}$, followed by $20 \mathrm{~min}$ of linear gradient elution to $45 \%$ Solvent A/55\% Solvent B and a subsequent 8 min hold. Thereafter the system was returned to the initial conditions within $5 \mathrm{~min}$ and re-equilibrated for $15 \mathrm{~min}$.

Protein oxidation. Detection of protein carbonyl groups as a measure of protein oxidative modifications was carried out after Levine et al. (1990). Samples were homogenised in $50 \mathrm{mM}$ HEPES $(125 \mathrm{mM} \mathrm{KCl}$, $0.5 \mathrm{mg} \mathrm{ml}^{-1}$ leupeptine, $0.7 \mathrm{\mu g} \mathrm{ml}^{-1}$ pepstatine, $40 \mu \mathrm{g}$ $\mathrm{ml}^{-1}$ phenylmethylsulfonyl fluoride, $0.5 \mathrm{\mu g} \mathrm{ml}^{-1}$ aprotinine, $1.1 \mathrm{mM}$ EDTA, $0.6 \mathrm{mM} \mathrm{MgSO}_{4}$ ) and centrifuged at $31000 \times g$ for $15 \mathrm{~min}$. Supernatants were incubated for $1 \mathrm{~h}$ with $10 \mathrm{mM}$ DNTP (2,4-dinitrophenylhydrazine) in $2 \mathrm{M}$ HCL. Blanks were run without DNTP. After incubation, $100 \%$ trichloroacetic acid (TCA) was added to the sample to precipitate the protein, followed by centrifugation for $10 \mathrm{~min}$ at $11000 \times \mathrm{g}$. The protein pellet was washed 3 times with ethanol: ethylacetate (1:1) and resuspended in $6 \mathrm{M}$ guanidine hydrochloride in $20 \mathrm{mM}$ potassium phosphate $(\mathrm{pH}=$ 2.3). Samples were measured photometrically at $360 \mathrm{~nm}$ using guanidine hydrochloride as a reference. The protein content of the samples was determined according to Bradford (1976), using bovine serum albumin as a standard.
Fluorescent age pigment, lipofuscin. Lipofuscin contents were determined by an extraction method modified after Vernet et al. (1988), as described in Philipp et al. (2005a). The fluorescence intensity of each sample was determined at an emission maximum of $450 \mathrm{~nm}$ for Aequipecten opercularis and $435 \mathrm{~nm}$ for Adamussium colbecki. Following Hill \& Womersley (1991), lipofuscin concentrations were expressed as relative fluorescent intensity (RFI) using $0.1 \mu \mathrm{g}$ quinine sulphate $\mathrm{ml}^{-1} 1 \mathrm{~N} \mathrm{H}_{2} \mathrm{SO}_{4}$ as standard.

Protein content. Protein content was determined as described by Philipp et al. (2005a). Lyophilised mantle tissue of both species was hydrolysed with $3 \% \mathrm{NaOH}$. Samples were centrifuged for $20 \mathrm{~min}$ at $10000 \times g$ to remove cell debris, and cooled on ice to facilitate protein precipitation. We added $60 \%$ TCA to precipitate the protein. After $20 \mathrm{~min}$ at $10000 \times g$, the supernatant was discharged and the pellet dissolved in $3 \% \mathrm{NaOH}$ using $20 \mathrm{ml}$ per initial $\mathrm{g}$ tissue dry mass. Protein concentration was determined spectrophotometrically with the biuret method.

Statistical analysis. Analysis of variance (ANOVA) and analysis of covariance (ANCOVA) were used to analyse the relationship between individual parameters and age and to identify differences between species after testing the data for normality. Differences in $Q_{10}$ values between species were analysed with a Student's $t$-test.

\section{RESULTS}

Relations between shell height and age were welldescribed by the von Bertalanffy growth model in both species (Fig. 1). Age can be inferred from shell height by Age $t=\ln \left(1-H_{t} / 108.74\right) /-0.199+(-1.115), \mathrm{N}=276$, mean squared error (MSE) $=0.370$ in Aequipecten opercularis, and by Age $t=\ln \left(1-H_{t} / 122.61\right) /-0.083+$ $0.237, \mathrm{~N}=185, \mathrm{MSE}=0.178$. in Adamussium colbecki.

\section{Metabolism}

Respiration rates $\left(R=\mu \mathrm{g} \mathrm{O} \mathrm{O}_{2}\right.$ ind $\left.^{-1} \mathrm{~h}^{-1}\right)$ of Aequipecten opercularis correlated well with body mass, $M$ (mg AFDM) (Fig. 2): Aequipecten opercularis $\left(10^{\circ} \mathrm{C}\right)$ : $\log (R)=0.647 \times \log (M)+0.447\left(\mathrm{~N}=31, \mathrm{r}^{2}=0.864, \mathrm{p}<\right.$ $0.001)$.

\section{Age-related changes in mitochondrial functions of Aequipecten opercularis}

Oxygen consumption of mantle tissue mitochondria $\left(R_{\mathrm{M}}, \mathrm{nmol} \mathrm{O} \mathrm{mg}^{-1}\right.$ protein $\left.\mathrm{min}^{-1}\right)$ at in situ temperature 

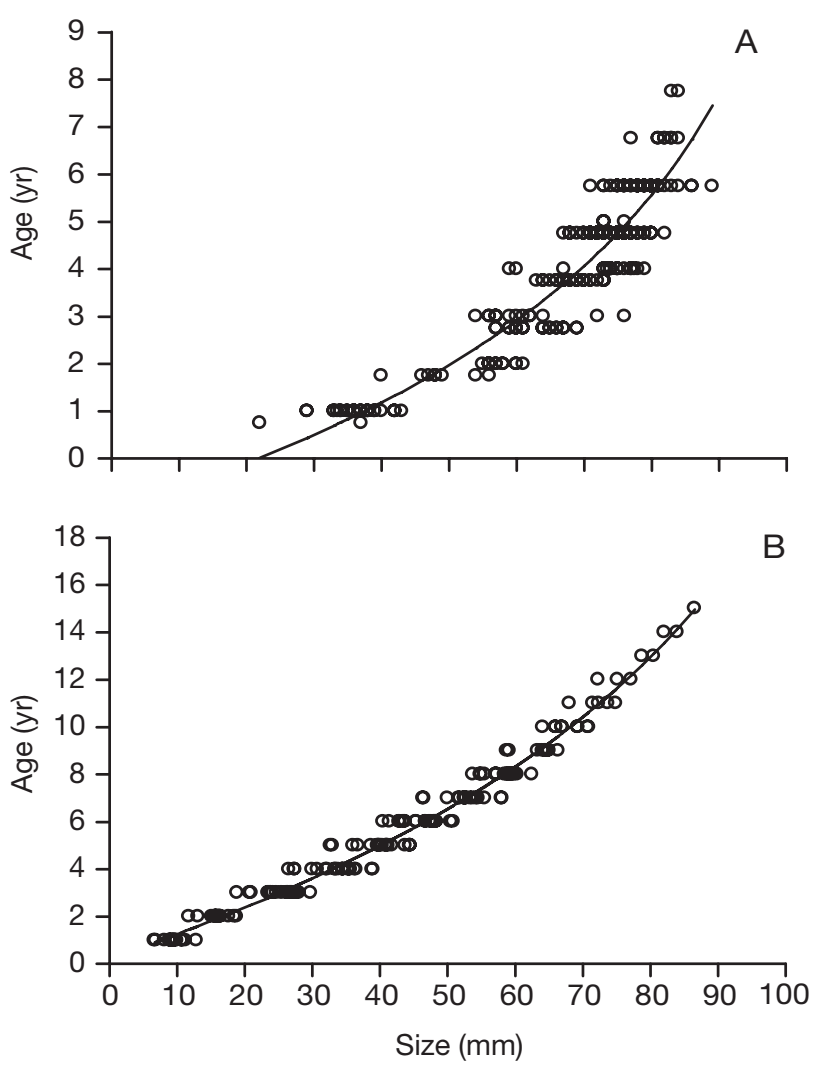

Fig. 1. (A) Aequipecten opercularis from Isle of Man: Age $t=$ $\ln \left(1-H_{t} / 108.74\right) /-0.199+(-1.115), \mathrm{N}=276$, mean squared error $(\mathrm{MSE})=0.370$; (B) Adamussium colbecki from Terra Nova Bay: Age $t=\ln \left(1-H_{t} / 122.61\right) /-0.083+0.237, \mathrm{~N}=185$, MSE $=0.178$. Inverse Von Bertalanffy growth models, where $H_{t}=$ height at Age $t$ estimating size from age: $H_{t}=84.47 \times(1-$ $\left.\mathrm{e}^{-0.427 \times(t+0.347)}\right), \mathrm{N}=276, \mathrm{MSE}=15.569$ for $A$. opercularis, and $H_{t}=126.30 \times\left(1-\mathrm{e}^{-0.078 \times(t-0.103)}\right), \mathrm{N}=185, \mathrm{MSE}=7.189$ for A. colbecki

$\left(10^{\circ} \mathrm{C}\right)$ declined significantly with increasing age (Fig. 3): $R_{\mathrm{M}}=-0.385 \times$ Age $+6.460\left(\mathrm{~N}=29, \mathrm{r}^{2}=0.245\right.$, $\mathrm{p}=0.0063$, age range $=1$ to $5 \mathrm{yr}$ ). The respiratory control ratio (RCR) and ADP:O ratio declined with age too, but the relationship was much weaker: $\mathrm{RCR}=-0.074 \times$ Age $+3.274\left(\mathrm{~N}=34, \mathrm{r}^{2}=0.111, \mathrm{p}=0.054\right.$, age range $=$ 1 to 5 yr $) ; \mathrm{ADP}: \mathrm{O}=-0.033 \times$ Age $+1.535\left(\mathrm{~N}=33, \mathrm{r}^{2}=\right.$ $0.118, \mathrm{p}=0.05$, Age range $=1$ to $5 \mathrm{yr}$.

Proton leak showed a slightly positive but non-significant relationship with age $(\mathrm{p}=0.120) . \mathrm{H}_{2} \mathrm{O}_{2}$ generation ( $\mathrm{nmol} \mathrm{H}_{2} \mathrm{O}_{2} \mathrm{mg}^{-1}$ protein $\mathrm{min}^{-1}$ ) of isolated mitochondria of Aequipecten opercularis was extremely low and followed no significant trend with age. Average values across the whole age range ( 1 to $5 \mathrm{yr}$ ) were $\mathrm{RCR}=3.070(\mathrm{SD} \pm 0.312, \mathrm{~N}=34), \mathrm{ADP}: \mathrm{O}=1.443(\mathrm{SD} \pm$ $0.133, \mathrm{~N}=33)$, proton leak $(\%)=32.84(\mathrm{SD} \pm 3.87, \mathrm{~N}=$ 34), $\mathrm{H}_{2} \mathrm{O}_{2}$ generation $\left(\mathrm{nmol} \mathrm{mg}^{-1}\right.$ protein $\left.\mathrm{min}^{-1}\right)=$ $0.0025(\mathrm{SD} \pm 0.0012, \mathrm{~N}=30)$.

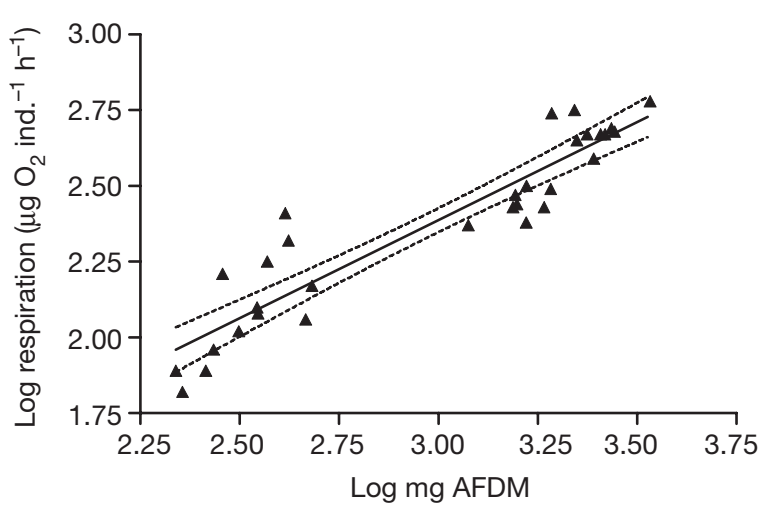

Fig. 2. Aequipecten opercularis. Standard metabolic rate. Respiration rates at $10^{\circ} \mathrm{C}$ : $\log (R)=0.646 \times \log ($ ash-free dry mass, AFDM) + 0.447; $\mathrm{r}^{2}=0.864, \mathrm{p}<0.001 . \mathrm{N}=31$; age range $=1$ to 6 yr. Here and in following figures, continuous line is regression line and dashed lines are upper and lower 95\% confidence limits

\section{Mitochondrial enzyme activities in mantle tissue of ageing Aequipecten opercularis and Adamussium colbecki}

Activities of mitochondrial enzymes CS and COX decreased significantly with increasing age in Aequipecten opercularis but not in Adamussium colbecki (Fig. 4). CS values measured at in situ temperatures (data not shown) did not differ significantly between both species as a function of age. At the reference temperature of $20^{\circ} \mathrm{C}$ (Fig. 4A), values were in the same range in young individuals of both species. With

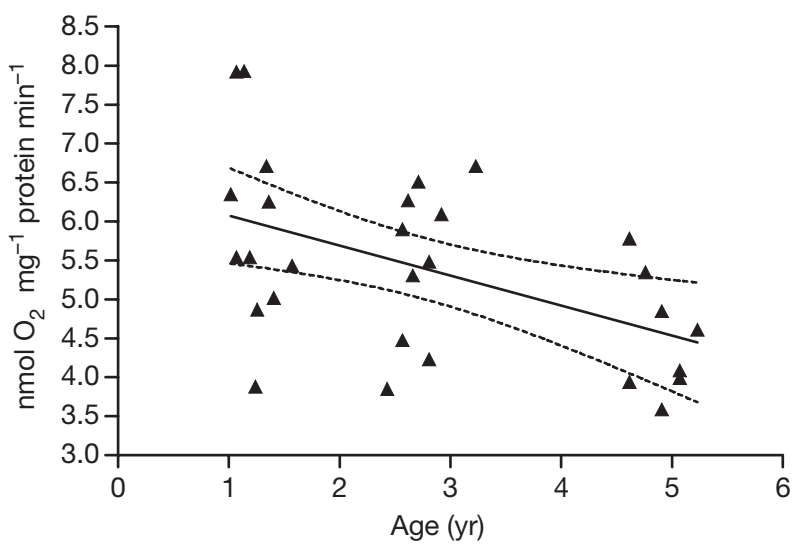

Fig. 3. Aequipecten opercularis. Decline in State 3 respiration of isolated mitochondria from mantle tissue at mean in situ temperature $\left(10^{\circ} \mathrm{C}\right)$ with increasing age. Data points represent 1 to 3 replicate measurements per mitochondrial isolation. $\mathrm{O}_{2}$ consumption of mantle tissue mitochondria, $R_{\mathrm{M}}=$ $0.385 \times$ Age $+6.46, \mathrm{~N}=29, \mathrm{r}^{2}=0.245, \mathrm{p}=0.0063$, Age range $=$ 1 to $5 \mathrm{yr}$ 


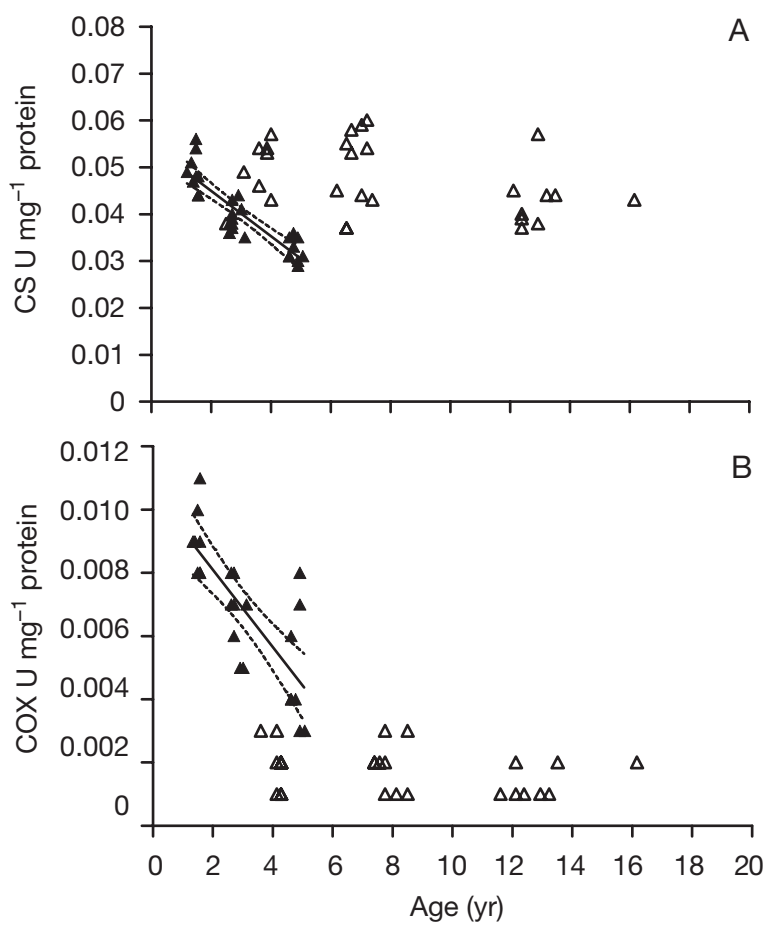

Fig. 4. Aequipecten opercularis ( $\mathbf{\wedge}$ ) and Adamussium colbecki $(\Delta)$. Activities of (A) citrate synthase (CS) and (B) cytochrome $c$ oxidase (COX) at $20^{\circ} \mathrm{C}$ in mantle tissue versus age. Data are means of 2 to 3 replicate measurements. Slopes differed significantly between species $(\mathrm{p}<0.001$, ANCOVA). CS: A. opercularis: $\mathrm{CS}=-0.0048 \times$ Age $+0.055, \mathrm{~N}=28, \mathrm{r}^{2}=0.786, \mathrm{p}<$ 0.001 , age range $=1$ to $5 \mathrm{yr}$ A. colbecki: no significant relationship, $\mathrm{N}=28$, age range $=2$ to $16 \mathrm{yr}$. COX: A. opercularis: $\mathrm{COX}=-0.00122 \times$ Age $+0.010, \mathrm{~N}=24, \mathrm{r}^{2}=0.601, \mathrm{p}<0.001$, age range $=1$ to $5 \mathrm{yr} ; A$. colbecki: no significant relationship, $\mathrm{N}=26$, age range $=2$ to $16 \mathrm{yr}$

advanced age ( $>5 \mathrm{yr})$, A. colbecki showed significantly higher values than $A$. opercularis. COX values were significantly higher in A. opercularis than in A. colbecki at both in situ and reference temperatures (Fig. 4B).

\section{Age-dependent changes in antioxidant defence mechanisms}

Activity of the antioxidant enzyme catalase $\left(\mathrm{U} \mathrm{mg}^{-1}\right.$ protein) decreased significantly with increasing age in both species, but with a 5 -fold faster decrement in Aequipecten opercularis compared to Adamussium colbecki. (Fig. 5). In young individuals, A. colbecki had lower catalase activities than A. opercularis. In old $A$. colbecki, however, activities were in the same range as in old A. opercularis. SOD activity ( $\mathrm{U} \mathrm{mg}^{-1}$ protein) was not affected by age in $A$. opercularis $(\mathrm{N}=27, \mathrm{p}=0.443$, age range $=1$ to $5 \mathrm{yr}$ ) and was assumed to be independent of age in $A$. colbecki also $(\mathrm{N}=5$, age range $=4$ to

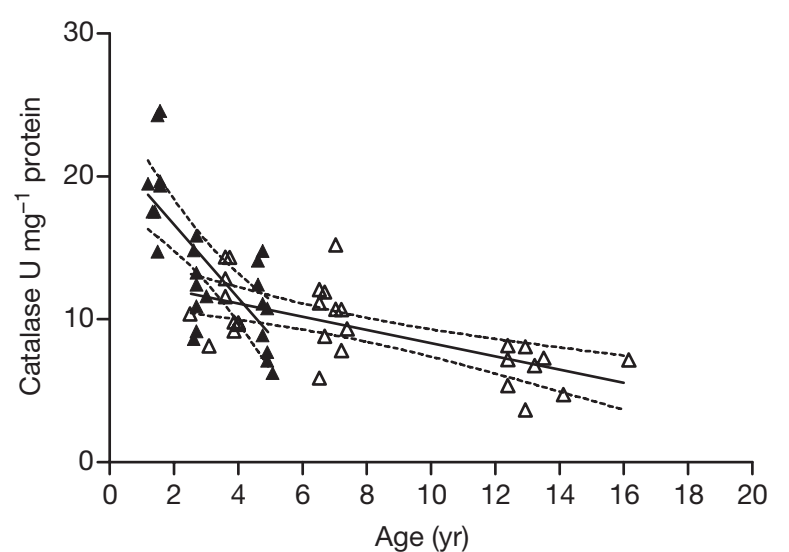

Fig. 5. Aequipecten opercularis ( $\mathbf{\Delta}$ ) and Adamussium colbecki $(\Delta)$. Activity of catalase at $20^{\circ} \mathrm{C}$ in mantle tissue versus age. Each symbol is mean of 2 to 3 replicate measurements. Slopes differed significantly between species ( $p<0.001$, ANCOVA). A. opercularis: catalase activity $=-2.564 \times$ Age $+21.75, \mathrm{~N}=$ $25, \mathrm{r}^{2}=0.540, \mathrm{p}<0.001$, age range $=1$ to $5 \mathrm{yr}_{;}$A. colbecki: catalase activity $=-0.463 \times$ Age $+12.97, \mathrm{~N}=29, \mathrm{r}^{2}=0.438$, $\mathrm{p}<0.001$, age range $=2$ to $16 \mathrm{yr}$

$8 \mathrm{yr})$. Mean $( \pm \mathrm{SD}) \mathrm{SOD}$ activities at $20^{\circ} \mathrm{C}$ were significantly lower in A. colbecki than in A. opercularis: 10.19 $( \pm 0.89, \mathrm{~N}=5)$ versus $12.77( \pm 2.63, \mathrm{~N}=27) \mathrm{U} \mathrm{mg}^{-1}$ protein $(\mathrm{p}=0.040$, Student's $t$-test), respectively.

$Q_{10}$ values of COX, SOD and catalase did not differ significantly between species (Students $t$-test, data not shown), but the $Q_{10}$ of CS was significantly lower in Adamussium colbecki $(1.54 \pm 0.11, \mathrm{~N}=15)$ than in Aequipecten opercularis $(1.74 \pm 0.15, \mathrm{~N}=30)$ at $\mathrm{p}<$ 0.001 .

In both Aequipecten opercularis and Adamussium colbecki, glutathione concentrations (GSH, GSSG,

Table 1. Aequipecten opercularis and Adamussium colbecki. Regression equations for whole (tGSH), reduced (GSH) and oxidised (GSSG) glutathione (nmol g ${ }^{-1}$ wet mass) and ratio of oxidised to reduced (GSSG:GSH) glutathione versus age (in years) in mantle tissue of $A$. opercularis and A. colbecki; $\mathrm{p}<0.001$ for all equations

\begin{tabular}{|lc}
\hline $\begin{array}{l}\text { Species } \\
\text { Equation }\end{array}$ & $\mathrm{r}^{2}$ \\
\hline A. opercularis (Age 1 to $5 \mathrm{yr} ; \mathrm{N}=28)$ & \\
tGSH $=-94.74 \times$ Age +904.1 & 0.727 \\
GSH $=-76.56 \times$ Age +788.0 & 0.664 \\
GSSG $=-9.092 \times$ Age +58.08 & 0.631 \\
GSSG:GSH $=-0.0098 \times$ Age +0.0824 & 0.399 \\
A. colbecki (Age 3 to 14 yr $; \mathrm{N}=26)$ & \\
tGSH $=-91.82 \times$ Age +1951 & 0.676 \\
GSH $=-60.56 \times$ Age +1448 & 0.653 \\
GSSG $=-14.61 \times$ Age +240.0 & 0.651 \\
GSSG:GSH $=-0.0081 \times$ Age +0.1861 & 0.524 \\
\hline
\end{tabular}



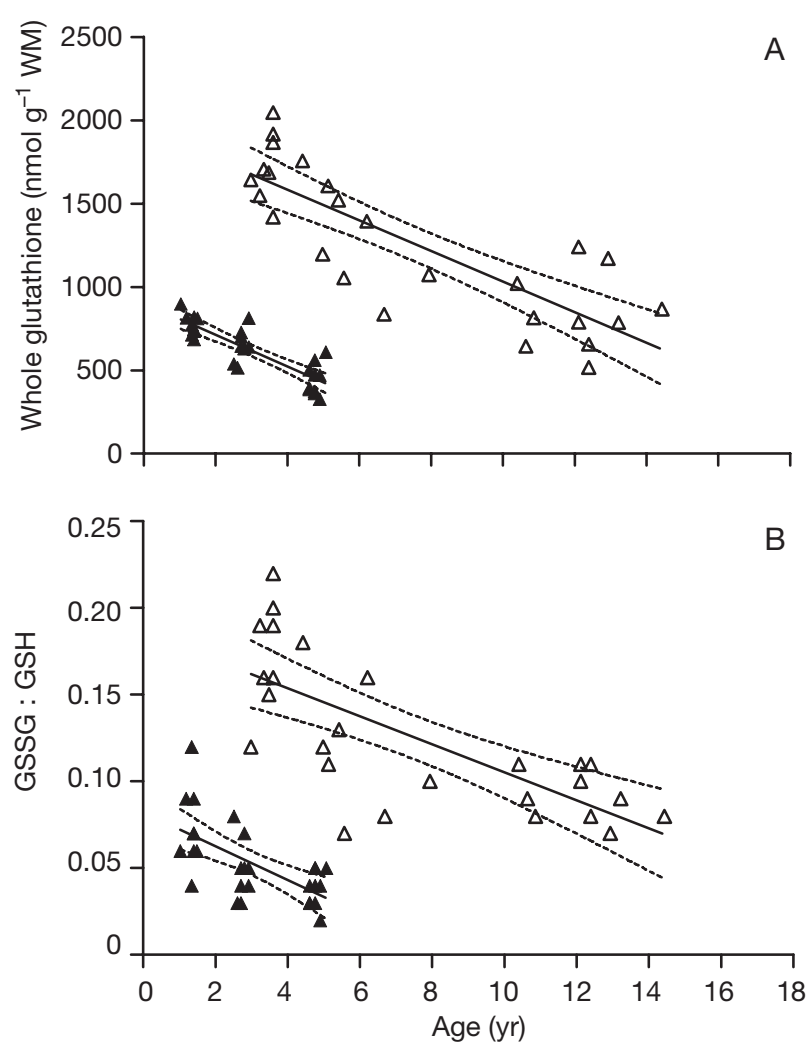

Fig. 6. Aequipecten opercularis $(\mathbf{\Lambda}, \mathrm{N}=28)$ and Adamussium colbecki $(\Delta, N=26)$. Decrease in (A) total glutathione (tGSH = $2 \times$ GSSG+GSH) and (B) ratio of oxidised to reduced glutathione (GSSG:GSH) in mantle tissue with age. Each symbol is mean of duplicate measurements of 1 or 3 to 4 pooled scallops. Slopes were not significantly different between species. A. opercularis: $\mathrm{tGSH}=-94.74 \times$ Age $+904.1, \mathrm{r}^{2}=0.727$; GSSG:GSH $=-0.0098 \times$ Age $+0.0824, \mathrm{r}^{2}=0.399 ;$ A. colbecki $\mathrm{tGSH}=-91.82 \times$ Age $+1951, \mathrm{r}^{2}=0.676 ;$ GSSG: GSH $=-0.0081$ $\times$ Age $+0.1861, r^{2}=0.524 . p>0.001$ for all equations. WM : wet body mass

tGSH (total GSH) $=2 \times$ GSSG + GSH) as well as the ratio of oxidised to reduced glutathione (GSSG:GSH) decreased significantly with increasing age $(p<0.001)$. Slopes did not differ significantly between the 2 species with respect to any parameter, but the intercepts did; i.e. all concentrations (ratios) were higher in $A$. colbecki than in $A$. opercularis across the whole age range (Table 1; Fig. 6: graph only shown for tGSH and GSSG:GSH ratio).

\section{Age-dependent changes in oxidative damage}

Lipofuscin accumulated with age in both species (Fig. 7). Lipofuscin concentrations were in the same range in both species, but accumulation occurred at a 3 times faster rate in Aequipecten opercularis. Protein carbonyl content, a marker for protein oxidation, did not vary with age in either species, but was significantly ( $p<0.001$ ) higher in Adamussium colbecki (1.319 nmol carbonyls $\mathrm{mg}^{-1}$ protein $\pm 0.181, \mathrm{~N}=24$ ) than in A. opercularis (1.016 nmol carbonyls $\mathrm{mg}^{-1}$ protein $\pm 0.072, \mathrm{~N}=24$ )

\section{Age-related changes in protein content of mantle tissue}

Mantle tissue protein content showed opposing trends with age in the 2 species (Fig. 8). In Aequipecten opercularis, protein concentrations decreased

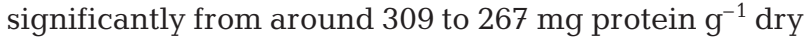
mass between 1 and 5 yr of age, whereas in Adamussium colbecki they increased from around 193 to $290 \mathrm{mg}$ protein $\mathrm{g}^{-1}$ dry mass between individuals aged 4 to 16 yr.

\section{DISCUSSION}

\section{Metabolic rate}

According to the predictions of the 'free radical-rate of living' theory (Pearl 1928, Harman 1956) low SMR of marine ectotherms living at low temperatures might be a prime reason for higher maximum lifespans in these animals compared to their temperate counterparts. Recent studies of pectinid SMR are in line with this hypothesis and revealed a positive relation of metabolic rates and ambient temperature across a wide latitudinal gradi-

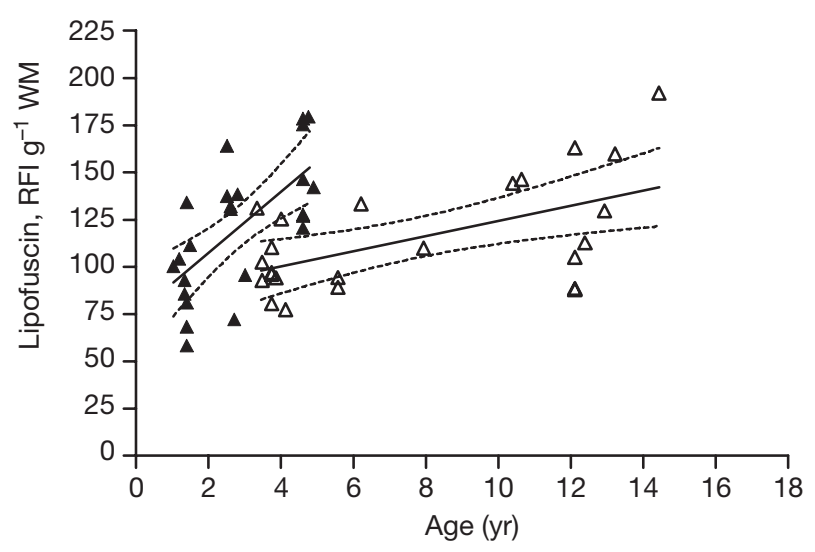

Fig. 7. Aequipecten opercularis ( $\mathbf{\Lambda}$ ) and Adamussium colbecki $(\Delta)$. Lipofuscin content (relative fluorescence intensity, RFI, $\mathrm{g}^{-1}$ wet mass, WM) in the mantle tissue versus age. Slopes differed significantly between species $(\mathrm{p}=0.003$, ANCOVA). A. opercularis: lipofuscin $=16.24 \times$ Age $+74.88 ; \mathrm{N}=24, \mathrm{r}^{2}=$ $0.453, \mathrm{p}<0.001$, age range $=1$ to $5 \mathrm{yr}$ A. colbecki: lipofuscin $=$ $4.009 \times$ Age $+84.27 ; \mathrm{N}=24, \mathrm{r}^{2}=0.312 ; \mathrm{p}=0.005$, age range $=$ 3 to $14 \mathrm{yr}$ 


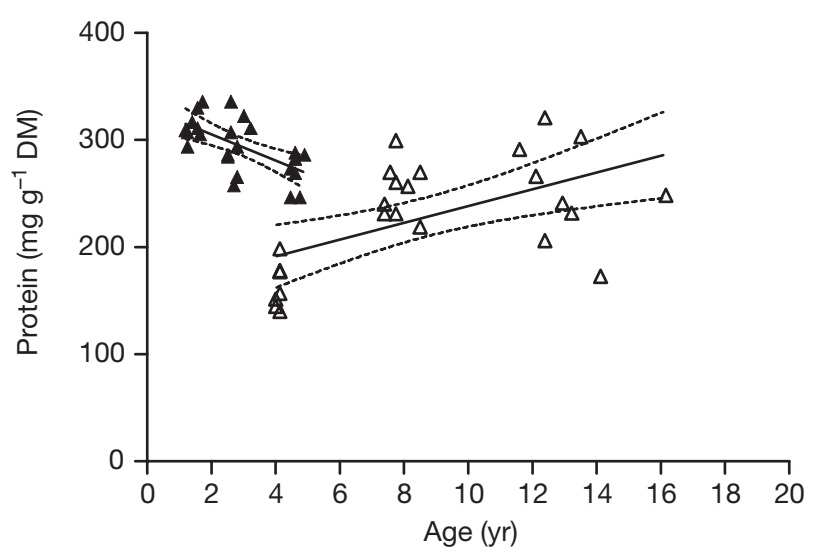

Fig. 8. Aequipecten opercularis $(\boldsymbol{\Lambda}, \mathrm{N}=25$, age range $=1$ to $5 \mathrm{yr})$ and Adamussium colbecki $(\Delta, \mathrm{N}=25$, age range $=4$ to $16 \mathrm{yr})$ protein content $\left(\mathrm{mg}^{-1}\right.$ protein $\mathrm{g}^{-1}$ dry mass, DM) in mantle tissue of versus age. Data are means of duplicate measurements. Slopes differed significantly between species $(\mathrm{p}<$ 0.001, ANCOVA). A. opercularis: protein content $=-12.17 \times$ Age $+329.7, \mathrm{~N}=25, \mathrm{r}^{2}=0.396, \mathrm{p}<0.001 ;$ A. colbecki: protein content $=7.821 \times$ Age $+160.1, \mathrm{~N}=25, \mathrm{r}^{2}=0.324, \mathrm{p}=0.003$

ent (Heilmayer \& Brey 2003, Heilmayer et al. 2004a). In our study, the SMR of the temperate Aequipecten opercularis from the Isle of Man were measured. As no living individuals of the Antarctic Adamussium colbecki were available for SMR measurements, we used respiration and AFDM data of Heilmayer \& Brey (2003 and pers. comm.) ( $\mathrm{N}=85$, mass range 104 to $3911 \mathrm{mg}$ AFDM, size range 27 to $74 \mathrm{~mm}$, age range 3 to 10 yr) from a Terra Nova Bay population, measured in austral summer during January and February 2000. A. opercularis reaches maturity at the end of its first year (Aravindakshan 1955), while A. colbecki is reported to reach maturity at 6 to $7 \mathrm{yr}$ (Cattaneo-Vietti et al. 1997). Therefore, in both data sets a similar proportion of immature and mature individuals were present. Whole animal specific metabolic rates of temperate and Antarctic scallop species were lower in small (young) Antarctic A. colbecki individuals than in temperate $A$. opercularis of the same body size (200 to $500 \mathrm{mg}$ AFDM), which is in line with the pattern reported by Heilmayer et al. (2004a). This difference, however, diminished with increasing body mass and became negligible above $1200 \mathrm{mg}$ AFDM, corresponding to individual ages of $>2 \mathrm{yr}$ in A. opercularis and $>6$ yr in $A$. colbecki $(95 \%$ confidence range of the predicted values overlap completely after $1200 \mathrm{mg}$ body massis attained: Fig. 9). The similar SMR in the older individuals of both species may be related to the fact that in A. opercularis individuals up to $6 \mathrm{yr}$ of age were studied, representing a significant proportion of the whole age range, whereas $A$. colbecki were measured only up to $10 \mathrm{yr}$ of age, presumably covering only a small fraction of their overall lifespan. In $A$. opercularis, respiration of old molluscs could already be depressed by age effects (Sukhotin \& Pörtner 2001), thus reducing the scaling exponent of the overall SMR versus body mass relation. In A. colbecki, individuals of $10 \mathrm{yr}$ can be classified as 'young', and presumably do not experience an age-related depression in respiration. Adding more data sets on the respiration of $A$. opercularis obtained by other authors did not alter the overall picture: the scaling exponent remained significantly smaller in A. opercularis, regardless of the combination of analysed data sets. Nevertheless, in the smaller and middle size classes, respiration rates of $A$. opercularis were distinctly higher than those of A. colbecki (Fig. 9). Obviously, this is a preliminary conclusion based on incomplete evidence. For a more reliable comparison, year-round measurements of respiration for both species, and over a wider age range for $A$. colbecki, are required in order to take age as well as environmental effects into account, since metabolic rates can be affected heavily by somatic growth, gonad development and environmental parameters such as food availability and increased temperature (Peck et al. 1987, Clarke 1988, Shumway et al. 1988, Peck 1998, Brockington 2001, Lesser \& Kruse 2004). Hence the question arises as to whether other parameters such as mitochondrial ageing, antioxidant defence and oxidative damage are more distinctly different, and whether these parameters show different trends with age in both species that might explain the higher MLSP of the polar scallop.

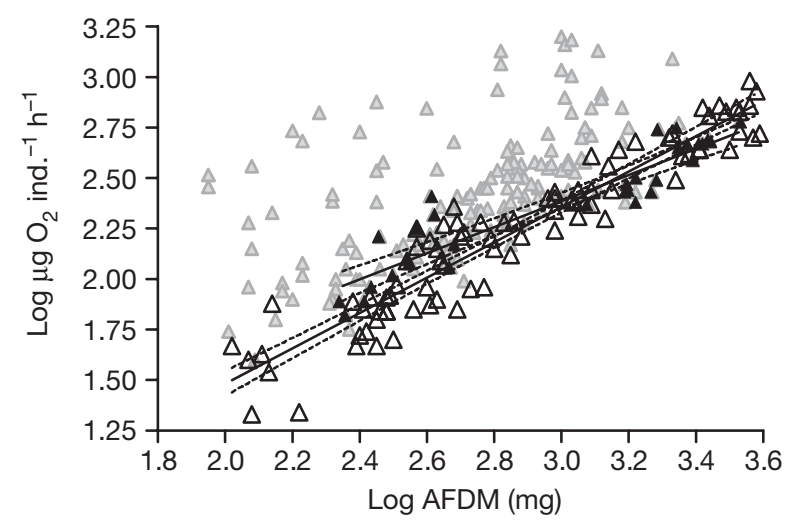

Fig. 9. Aequipecten opercularis and Adamussium colbecki. Metabolic rates $\left(\mu \mathrm{g} \mathrm{O}_{2} \mathrm{~h}^{-1}\right.$ ind. $\left.{ }^{-1}\right)$. Temperate $A$. opercularis from $(\mathbf{\Lambda})$ present study $\left(T=10^{\circ} \mathrm{C}\right)$ and $(\mathbf{\Lambda})$ from Heilmayer et al. (2004b) $\left(T=10.2,12.4,14.4^{\circ} \mathrm{C}\right)$, McLusky (1973) $(T=5,10$, $\left.15^{\circ} \mathrm{C}\right)$ and Vahl $(1972)\left(T=12^{\circ} \mathrm{C}\right) .(\Delta)$ Antarctic A. colbecki from Heilmayer \& Brey $(2003)\left(T=0^{\circ} \mathrm{C}\right)$. For equation details for linear regression of $A$. opercularis from present study see Fig. 2 ; for $A$. colbecki, $\log (R)=0.876 \times \log (\mathrm{AFDM})-0.269 ; \mathrm{r}^{2}=$ $0.899, \mathrm{p}<0.001$. $\mathrm{N}=85$, age range $=3$ to $10 \mathrm{yr}$ 


\section{Mitochondrial ageing}

Age-related changes in mitochondrial function (respiration, $\mathrm{RCR}, \mathrm{ADP}: \mathrm{O}$ and proton leak) in mantle tissue of Aequipecten opercularis were small (Fig. 3), but followed a pattern already known for humans (Trounce et al. 1989, Cooper et al. 1992, Boffoli et al. 1994), other terrestrial vertebrates (Goodell \& Cortopassi 1998, Kokoszka et al. 2001, Hagen et al. 2002, Lopez-Torres et al. 2002, Ventura et al. 2002, Grattagliano et al. 2004), and invertebrates (Sohal et al. 1995) including marine bivalves (Philipp et al. 2005b). Protein-specific activities of the mitochondrial enzymes CS and COX declined significantly with increasing age in A. opercularis, as found in humans, rats and mice (Paradies et al. 1993, 1997, Rooyackers et al. 1996, Kokoszka et al. 2001). This change is held responsible for the decline in aerobic capacity and muscle performance associated with age in most organisms (Rooyackers et al. 1996). In contrast to A. opercularis, mitochondrial enzyme activities were independent of age in A. colbecki (Fig. 4). The relevance of stable CS and COX activities for delayed mitochondrial senescence remains questionable, as mitochondrial functions could not be measured directly in A. colbecki. In the infaunal soft-shell clams Mya arenaria (MLSP 13 yr) and Laternula elliptica (MLSP 36 yr) CS and COX activities were stable, but the decline in mitochondrial functions in $M$. arenaria was even more pronounced than in A. opercularis (Philipp et al. 2005b). Regarding energy conservation, however, stable CS and COX activities in A. colbecki might play a role in lifespan extension, as they indicate better preservation of tissue aerobic capacity with age.

The very minor age-related decline in mitochondrial functioning of Aequipecten opercularis came as a complete surprise, as we would have expected a more rigid onset of mitochondrial deterioration in this short-lived and actively swimming species, especially when compared to the sessile mud clams. Moreover, $\mathrm{H}_{2} \mathrm{O}_{2}$ generation rates with either succinate plus rotenone, or pyruvate and malate (without rotenone), or at higher assay temperatures $\left(20^{\circ} \mathrm{C}\right)$ were close to zero in $A$. opercularis, despite intense mitochondrial respiration and a lower proton leak $(33 \%)$. In contrast, the longerlived temperate soft-shell clam Mya arenaria showed far higher $\mathrm{H}_{2} \mathrm{O}_{2}$ generation rates $\mathrm{mg}^{-1}$ mitochondrial protein than A. opercularis, despite lower State 3 respiration rates (individuals $>5 \mathrm{yr}$ ) and a generally higher mitochondrial proton leak (Philipp et al. 2005b).

The lower proton leak of Aequipecten opercularis mitochondria compared to mitochondria of the less active infaunal bivalves Mya arenaria and Laternula elliptica (Philipp et al. 2005b), corresponds to the more active lifestyle of the scallop. Following Brand's (2000) rationale of mild uncoupling, less proton leakage would, however, cause higher rather than lower ROS generation. This raises the question as to whether some special mechanism may prevent ROS generation in mitochondria of A. opercularis, or even of scallops in general. Preliminary data point in this direction, as $\mathrm{H}_{2} \mathrm{O}_{2}$ generation rates $\left(\right.$ at $0^{\circ} \mathrm{C}$ ) of mitochondria isolated from 3 available live Adamussium colbecki individuals were below detection limits in States 3 and 4, whereas in the polar mud clam L. elliptica $\mathrm{H}_{2} \mathrm{O}_{2}$ generation of isolated mitochondria amounted to $0.03 \mathrm{nmol} \mathrm{H}_{2} \mathrm{O}_{2}$ $\mathrm{min}^{-1} \mathrm{mg}^{-1}$ protein at $0^{\circ} \mathrm{C}$ (Philipp et al. 2005b).

Higher glutathione concentrations were found in the tissues of Aequipecten opercularis and Adamussium colbecki than in tissue of mud clams from comparable temperature regimes (Philipp et al. 2005a), but GSSG concentrations and tissue redox-states (GSSG:GSH) were lower in the scallops than in temperate and polar mud clams (Philipp et al. 2005a). This indicates lower ROS scavenging activity of the glutathione system in scallops and would coincide with lower rates of mitochondrial ROS production. Moreover, comparable or lower catalase and SOD activity levels in scallops than in mud clams indicate that the more active scallop lifestyle does not imply vastly higher mitochondrial ROS formation.

In both scallop species, the concentration of tissue glutathione decreased linearly with increasing age (Fig. 6A, Table 1), which is in line with findings for humans, rats, insects and marine bivalves (Sohal et al. 1987, Sanz et al. 1996, Canesi \& Viarengo 1997, Hernanz et al. 2000, Philipp et al. 2005a). Likewise, the ratio of GSSG:GSH decreased with increasing age in both species (Fig. 6B). Thus, we suggest that the scallops adjust their glutathione content to match the mass and age-related decline in mass-specific respiration. Whereas in Adamussium colbecki the decline in massspecific respiration might be a mere effect of the increase in size and not related to age, this could be the case for Aequipecten opercularis, and has previously been reported for Mytilus edulis (Sukhotin \& Pörtner 2001). As reported for the polar clam Laternula elliptica, for which a similar development of GSH concentration and tissue redox-ratio was found, the glutathione level should suffice to maintain low tissue oxidation in older individuals (Philipp et al. 2005a).

In contrast to the uniform decrease in glutathione, the decrease in catalase activity was much more pronounced in Aequipecten opercularis than in Adamussium colbecki, indicating a more rapid loss of antioxidant capacity with advancing age in the temperate scallop. Accordingly, the increase in lipofuscin concentrations was more pronounced in the temperate scallop, indicating faster oxidation of lipids and proteins in A. opercularis with increasing age, as antioxidative capacity declined. 
The comparatively slow increase in lipofuscin levels (Fig. 7) and the preservation of mantle protein content (Fig. 8) with increasing age in Adamussium colbecki support the idea that avoidance of waste accumulation and maintenance of cellular integrity are prerequisites of longevity in the polar scallop. The higher protein carbonyl content in A. colbecki than in Aequipecten opercularis might therefore not necessarily reflect higher protein oxidation rates, but might result from thermally reduced proteolytic activity in A. colbecki, leading to higher steady-state levels of oxidized protein at an ambient water temperature of $0^{\circ} \mathrm{C}$. Further studies are necessary to prove this hypothesis.

\section{Importance of maintenance of physiological performance in active animals throughout their lifetime}

Mitochondria from mantle tissue of their temperate scallop Aequipecten opercularis, exhibit a slower senescence than mitochondria from the temperate mud clam Mya arenaria (Philipp et al. 2005b), most probably due to a suppression of mitochondrial ROS production in the scallop. CS and COX activities, however, decrease with increasing age in the mantle of $A$. opercularis, whereas they remained constant in $M$. arenaria. This could indicate an age-related decrease in mitochondrial numbers in the mantle tissue of $A$. opercularis and, therefore, a loss in tissue aerobic capacity with increasing age. So far, age-related changes in mitochondrial numbers per cell have only been reported for human liver (Tauchi \& Sato 1968).

A prerequisite for an active lifestyle is the maintenance of cellular functions and fitness on a high level to insure maximal scope for activity. Aequipecten opercularis is an active swimmer, with fast escape reactions when disturbed (see e.g. Chapman 1981). The Antarctic Adamussium colbecki features the same active lifestyle in order to escape scouring icebergs and predators such as the fish Trematomus bernacchii and invertebrates (e.g. Neobuccinum eatoni, Paraborlasia corrugata) (Ansell et al. 1998, Vacchi et al. 2000, Peck et al. 2004). A comparison of mature and immature Chlamys islandica showed that reduced CS activity and mitochondrial capacity caused a decrease in the aerobic capacity of adductor muscle in mature specimens and subsequently a delay in recovery after exhaustive swimming, which requires aerobic metabolism (Livingstone et al. 1981, Brokordt et al. 2000). Hence, a decrease in mitochondrial capacity and a decline in CS and COX activity with increasing age, as found in A. opercularis, may significantly reduce fitness in older specimens. Corresponding observations were reported by Brand (1991), who found a higher threshold stimulus to elicit swimming and less frequent swimming in larger (older) A. opercularis. This in turn could cause an increase in extrinsic mortality (= elevated susceptibility to predation) and thus a comparatively shorter MLSP in such highly active animals. On an evolutionary scale, these scallops may have adjusted their life history and physiological ageing strategies to an optimal functioning until a threshold after which maintenance of physiological competitive capacities requires more energy than justified by the reproductive gain. Theoretical studies by Abrams (1993) and Williams \& Day (2003) presented the rationale that an increase in interactive extrinsic sources of mortality (e.g. predation) may select for slower senescence deterioration early in life. A recent study by Reznick et al. (2004) on guppies indicates such a relation between predation pressure and senescence. Although scientific proof for the validity of this concept for A. opercularis has still to be put forward, these ideas offer an explanation for the combination of short MLSP and minor decrements in mitochondrial functions with increasing age in $A$. opercularis. In the Antarctic A. colbecki, CS and COX activities remained stable over a lifespan of $16 \mathrm{yr}_{\text {; }}$ hence loss of fitness and corresponding increase in extrinsic mortality may be delayed until a higher age. However, individuals across the full age-range must be studied to discover whether physiological fitness in A. colbecki is also preserved until close to its MSLP, as in A. opercularis.

Acknowledgements. A. R. Brand, B. Veale and B. BeukersStewart kindly provided work space at the Port Erin Marine Laboratory of the University of Liverpool for E.P. and helped on several sampling trips to collect Aequipecten opercularis. Many thanks to S. Gatti, P. Rehm and M. Chiantore, who collected Adamussium colbecki in Terra Nova Bay, and the PNRA (Italian National Programme for Antarctic Research), which undertook the transport to the Alfred Wegener Institute in Bremerhaven. E. Allison kindly provided additional lengthat-age data for the von Bertalanffy growth function (VBGF) of Aequipecten opercularis. We also thank 3 anonymous referees for their helpful comments and corrections. The study was supported by a student grant of the University of Bremen.

\section{LITERATURE CITED}

Abrams PA (1993) Does increased mortality favor the evolution of more rapid senescence? Evolution 47:877-887

Aebi H (1984) Catalase in vitro. Methods Enzymol 105: $121-126$

Allison EH (1993) The dynamics of exploited populations of scallops (Pecten maximus L.) and queens (Chlamys opercularis L.) in the North Irish Sea. PhD thesis, University of Liverpool

Ansell AD, Dao JC, Mason J (1991) Three European scallops: Pecten maximus, Chlamys (Aequipecten) opercularis and C. (Chlamys) varia. In: Shumway SE (ed) Scallops: biology, ecology and aquaculture. Elsevier, Amsterdam, p 715-751

Ansell AD, Cattaneo-Vietti R, Chiantore M (1998) Swimming 
in the Antarctic scallop Adamussium colbecki: analysis of in situ video recordings. Antarct Sci 10:369-375

Aravindakshan I (1955) Studies on the biology of the queen scallop, Chlamys opercularis (L.). PhD thesis, University of Liverpool

Benson BB, Krause DJ (1984) The concentration and isotopic fractionation of oxygen dissolved in freshwater and seawater in equilibrium with the atmosphere. Limnol Oceanogr 29:620-632

Berkman PA (1990) The population biology of the Antarctic scallop, Adamussium colbecki (Smith 1902) at New Harbor, Ross Sea. In: Kerry KR, Hempel G (eds) Antarctic ecosystems. Ecological change and conservation, Springer-Verlag, Berlin, p 281-288

Berkman PA, Cattaneo-Vietti R, Chiantore M, HowardWilliams C (2004) Polar emergence and the influence of increased sea-ice extent on the Cenozoic biogeography of pectinid molluscs in Antarctic coastal areas. Deep-Sea Res 11:1839-1855

Boffoli D, Scacco SC, Vergari R, Solarino G, Santacroce G, Papa $S$ (1994) Decline with age of the respiratory chain activity in human skeletal muscle. Biochim Biophys Acta 1226:73-82

Bradford MM (1976) A rapid and sensitive method for the quantitation of microgram quantities of protein utilizing the principle of protein-dye binding. Anal Biochem 72:248-254

Brand AR (1991) Scallop ecology: distributions and behaviour. In: Shumway SE (ed) Scallops: biology, ecology and aquaculture. Elsevier, Amsterdam, p 517-584

Brand MD (1995) Measurement of mitochondrial protonmotive force. In: Brown GC, Cooper CE (eds) Bioenergetics: a practical approach. Oxford University Press, Oxford, p 39-62

Brand MD (2000) Uncoupling to survive? The role of mitochondrial inefficiency in ageing. Exp Gerontol 35:811-820

Brey T (1991) Population dynamics of Sterechinus antarcticus (Echinodermata: Echinoidea) on the Weddell Sea shelf and slope, Antarctica. Antarct Sci 3:251-256

Brey T, Pearse J, Basch L, McCintock J, Slattery M (1995) Growth and production of Sterechinus neumayeri (Echinoidae: Echinodermata) in McMurdo Sound, Antarctica. Mar Biol 124:279-292

Brockington S (2001) The seasonal energetics of the Antarctic bivalve Laternula elliptica (King and Broderip) at Rothera Point, Adelaide Island. Polar Biol 24:523-530

Brokordt KB, Himmelman JH, Guderley HE (2000) Effect of reproduction on escape responses and muscle metabolic capacities in the scallop Chlamys islandica Muller 1776. J Exp Mar Biol Ecol 251:205-225

Cailliet GM, Andrews AH, Burton EJ, Watters DL, Kline DE, Ferry-Graham LA (2001) Age determination and validation studies of marine fishes: Do deep-dwellers live longer? Exp Gerontol 36:739-764

Canapa A, Barucca M, Marinelli A, Olmo E (2000) Molecular data from the 16S rRNA gene for the phylogeny of Pectinidae (Mollusca: Bivalvia). J Mol Evol 50:93-97

Canesi L, Viarengo A (1997) Age-related differences in glutathione metabolism in mussel tissues (Mytilus edulis L.). Comp Biochem Physiol B 116:217-221

Cattaneo-Vietti R, Chiantore M, Albertelli G (1997) The population structure and ecology of the Antarctic scallop Adamussium colbecki (Smith, 1902) at Terra Nova Bay (Ross Sea, Antarctica). Sci Mar 61:15-24

Chapman CJ (1981) The swimming behaviour of queens in relation to trawling. Scott Fish Bull 46:7-10

Chiantore M, Cattaneo-Vietti R, Heilmayer O (2003) Antarc- tic scallop (Adamussium colbecki) annual growth rate at Terra Nova Bay. Polar Biol 26:416-419

Clarke A (1988) Seasonality in the antarctic marine environment. Comp Biochem Physiol B 90B:461-473

Cooper JM, Mann VM, Schapira AH (1992) Analyses of mitochondrial respiratory chain function and mitochondrial DNA deletion in human skeletal muscle: effect of ageing. J Neurol Sci 113:91-98

Estabrook RW (1967) Mitochondrial respiratory control and the polarographic measurement of $\mathrm{ADP} / \mathrm{O}$ ratios. In: Estabrook RW, Pullmann ME (eds) Enzymology. Academic Press, New York, p 41-47

Fariss MW, Reed DJ (1987) High-performance liquid chromatography of thiols and disulfides: dinitrophenol derivatives. Methods Enzymol 143:101-109

Gatti S, Brey T, Müller WEG, Heilmayer O, Holst G (2002) Oxygen microoptodes: a new tool for oxygen measurements in aquatic animal ecology. Mar Biol 140:1075-1085

Goodell S, Cortopassi G (1998) Analysis of oxygen consumption and mitochondrial permeability with age in mice. Mech Ageing Dev 101:245-256

Grattagliano I, Portincasa P, Cocco T, Moschetta A, Di Paola M, Palmieri VO, Palasciano G (2004) Effect of dietary restriction and N-acetylcysteine supplementation on intestinal mucosa and liver mitochondrial redox status and function in aged rats. Exp Gerontol 39:1323-1332

Hagen TM, Liu J, Lykkesfeldt J, Wehr CM, Ingersoll RT, Vinarsky V, Bartholomew JC, Ames BN (2002) Feeding acetyl-L-carnitine and lipoic acid to old rats significantly improves metabolic function while decreasing oxidative stress. Proc Natl Acad Sci USA 99:1870-1875

Hardewig I, van Dijk PL, Moyes CD, Pörtner HO (1999) Temperature-dependent expression of cytochrome-c oxidase in Antarctic and temperate fish. Am J Physiol 277:R508-516

Harman D (1956) Aging: a theory based on free radical and radiation biology. J Gerontol 11:298-300

Heilmayer O, Brey T (2003) Saving by freezing? Metabolic rates of Adamussium colbecki in a latitudinal context. Mar Biol 143:477-484

Heilmayer O, Brey T, Chiantore M, Cattaneo-Vietti R, Arntz WE (2003) Age and productivity of the Antarctic scallop, Adamussium colbecki, in Terra Nova Bay (Ross Sea, Antarctica). J Exp Mar Biol Ecol 288:239-256

Heilmayer O, Brey T, Pörtner HO (2004a) Growth efficiency and temperature in scallops: a comparative analysis of species adapted to different temperatures. Funct Ecol 18: 641-647

Heilmayer O, Brey T, Storch D, Mackensen A, Arntz WE (2004b) Population dynamics and metabolism of Aequipecten opercularis (L.) from the western English Channel (Roscoff, France). J Sea Res 52:33-44

Hernanz A, Fernandez-Vivancos E, Montiel C, Vazquez JJ, Arnalich F (2000) Changes in the intracellular homocysteine and glutathione content associated with aging. Life Sci 67:1317-1324

Hill KT, Womersley C (1991) Critical aspects of fluorescent age-pigment methodologies: modification for accurate analysis and age assessments in aquatic organisms. Mar Biol 109:1-11

Johnston IA, Guderley H, Franklin C, Crockford T, Kamunde C (1994) Are Mitochondria subject to evolutionary temperature adaptation? J Exp Biol 195:293-306

Keller M, Sommer AM, Pörtner HO, Abele D (2004) Seasonality of energetic functioning and production of reactive oxygen species by lugworm (Arenicola marina) mitochondria exposed to acute temperature changes. J Exp Biol 207:2529-2538 
Kokoszka JE, Coskun P, Esposito LA, Wallace DC (2001) Increased mitochondrial oxidative stress in the Sod2 $( \pm)$ mouse results in the age-related decline of mitochondrial function culminating in increased apoptosis. Proc Natl Acad Sci USA 98:2278-2283

Kresze GB (1988) Methods for protein determination. In: Bergmeyer HU (ed) Methods of enzymatic analysis. $\mathrm{VCH}$, Weinheim, p 84-88

Ku HH, Brunk UT, Sohal RS (1993) Relationship between mitochondrial superoxide and hydrogen peroxide production and longevity of mammalian species. Free Radic Biol Med 15:621-627

La Mesa M, Vacchi M (2001) Review. Age and growth of high Antarctic notothenioid fish. Antarct Sci 13:227-235

Lesser MP, Kruse VA (2004) Seasonal temperature compensation in the horse mussel, Modiolus modiolus: metabolic enzymes, oxidative stress and heat shock proteins. Comp Biochem Physiol A 137:495-504

Levine RL, Garland D, Oliver CN, Amici A and 5 others (1990) Determination of carbonyl content in oxidatively modified proteins. Methods Enzymol 186:464-478

Livingstone DR, De Zwaan A, Thompson RJ (1981) Aerobic metabolism, octopine production and phosphoarginine as sources of energy in the phasic and catch adductor muscles of the giant scollop Placopecten magellanicus during swimming and the subsequent recovery period. Comp Biochem Physiol B 70:35-44

Livingstone DR, Lips F, Garcia Martinez P, Pipe RK (1992) Antioxidant enzymes in the digestive gland of the common mussel Mytilus edulis. Mar Biol 112:265-276

Lopez-Torres M, Gredilla R, Sanz A, Barja G (2002) Influence of aging and long-term caloric restriction on oxygen radical generation and oxidative DNA damage in rat liver mitochondria. Free Radic Biol Med 32:882-889

McLusky DS (1973) The effect of temperature on the oxygen consumption and filtration rate of Chlamys (Aequipecten) opercularis (L.) (Bivalvia). Ophelia 10:141-154

Miwa S, St-Pierre J, Partridge L, Brand MD (2003) Superoxide and hydrogen peroxide production by Drosophila mitochondria. Free Radic Biol Med 35:938-948

Moyes CD, Moon TW, Ballantyne JS (1985) Glutamate catabolism in mitochondria from Mya arenaria mantle: effects of $\mathrm{pH}$ on the role of glutamate dehydrogenase. J Exp Zool 236:293-301

Moyes CD, Mathieu-Costello OA, Tsuchiya N, Filburn C, Hansford RG (1997) Mitochondrial biogenesis during cellular differentiation. Am J Physiol C 272:1345-1351

Paradies G, Ruggiero FM, Petrosillo G, Quagliariello E (1993) Age-dependent decrease in the cytochrome c oxidase activity and changes in phospholipids in rat-heart mitochondria. Arch Gerontol Geriatr 16:263-272

Paradies G, Ruggiero FM, Petrosillo G, Quagliariello E (1997) Age-dependent decline in the cytochrome c oxidase activity in rat heart mitochondria: role of cardiolipin. FEBS Lett 406:136-138

Pearl R (1928) The rate of living. Alfred Knopf, New York

Peck LS (1998) Feeding, metabolism and metabolic scope in Antarctic marine ectotherms. Semin Ser 66:365-390

Peck LS, Clarke A, Holmes LJ (1987) Summer metabolism and seasonal changes in biochemical composition of the Antarctic brachiopod Liothyrella uva (Broderip, 1833). J Exp Mar Biol Ecol 114:85-97

Peck LS, Webb KE, Bailey DM (2004) Extreme sensitivity of biological function to temperature in Antarctic marine species. Funct Ecol 18:625-630
Pérez-Campo R, Lopez-Torres M, Cadenas S, Rojas C, Barja $\mathrm{G}$ (1998) The rate of free radical production as a determinant of the rate of aging: evidence from the comparative approach. J Comp Physiol B 168:149-158

Philipp E, Brey T, Pörtner HO, Abele D (2005a) Chronological and physiological ageing in a polar and a temperate mud clam. Mech Ageing Dev 126:589-609

Philipp E, Pörtner HO, Abele D (2005b) Mitochondrial ageing of a polar and a temperate mud clam. Mech Ageing Dev 126:610-619

Reznick DN, Bryant MJ, Roff D, Ghalambor CK, Ghalambor DE (2004) Effect of extrinsic mortality on the evolution of senescence in guppies. Nature 431:1095-1099

Rooyackers OE, Adey DB, Ades PA, Nair KS (1996) Effect of age on in vivo rates of mitochondrial protein synthesis in human skeletal muscle. Proc Natl Acad Sci USA 93: 15364-15369

Sanz N, Diez-Fernandez C, Cascales M (1996) Variations of hepatic antioxidant systems and DNA ploidy in rats aged two to eight months. Biochim Biophys Acta 1315:123-130

Shumway SE, Barter J, Stahlnecker J (1988) Seasonal changes in oxygen consumption of the giant scallop, Placopecten magellanicus (Gmelin). J Shellfish Res 7:77-82

Sidell BD, Driedzic WR, Stowe DB, Johnston IA (1987) Biochemical correlations of power development and metabolic fuel preferende in fish hearts. Physiol Zool 60: 221-232

Sohal RS, Toy PL, Farmer KJ (1987) Age-related changes in the redox status of the housefly, Musca domestica. Arch Gerontol Geriatr 6:95-100

Sohal RS, Agarwal A, Agarwal S, Orr WC (1995) Simultaneous overexpression of copper- and zinc-containing superoxide dismutase and catalase retards age-related oxidative damage and increases metabolic potential in Drosophila melanogaster. J Biol Chem 270:15671-15674

Sukhotin AA, Pörtner HO (2001) Age-dependence of metabolism in mussels Mytilus edulis (L.) from the White Sea. J Exp Mar Biol Ecol 257:53-72

Tauchi H, Sato T (1968) Age changes in size and number of mitochondria of human hepatic cells. J Gerontol 23: $454-461$

Trounce I, Byrne E, Marzuki S (1989) Decline in skeletal muscle mitochondrial respiratory chain function: possible factor in ageing. Lancet 1:637-639

Vacchi M, Cattaneo-Vietti R, Chiantore M, Dalu M (2000) Predator-prey relationship between the nototheniid fish Trematomus bernacchi and the Antarctic scallop Adamussium colbecki. Ant Sci 12:64-68

Vahl O (1972) Particle retention and relation between water transport and oxygen uptake in Chlamys opercularis (L.) (Bivalvia). Ophelia 10:67-74

Ventura B, Genova ML, Bovina C, Formiggini G, Lenaz G (2002) Control of oxidative phosphorylation by Complex I in rat liver mitochondria: implications for aging. Biochim Biophys Acta 1553:249-260

Vernet M, Hunter JR, Vetter RD (1988) Accumulation of agepigments (lipofuscin) in two cold-water fishes. Fish Bull US Dep Comm 86:401-407

Williams PD, Day T (2003) Antagonistic pleiotropy, mortality source interactions, and the evolutionary theory of senescence. Evolution 57:1478-1488

Ziuganov V, Miguel ES, Neves RJ, Longa A and 6 others (2000) Life span variation of the freshwater pearl shell: a model species for testing longevity mechanisms in animals. Ambio 29:102-105

Submitted: February 2, 2005; Accepted: July 15, 2005

Proofs received from author(s): December 8, 2005 